\title{
A SPEECH ACT ANALYSIS OF WRITTEN ADVERTISEMENT OF COSMETIC BRAND IN INDONESIA
}

\author{
Nanda Aditria ${ }^{1}$, Rissa San Rizqiya ${ }^{2}$ \\ 1,2 IKIP Siliwangi \\ ${ }^{1}$ Nandaaditria28@ gmail.com, ${ }^{2}$ rissa.sr@gmail.com
}

\begin{abstract}
Advertising is a tool for creating communication and can promote goods or other products to everyone or what customers call using binding language. Every language uses good language to attract customers. The main purpose of advertising is the point of view to promote and promise an item. This study used qualitative research from several cosmetic advertisements. This ad uses 16 types of speech acts, and out of 16 types of speech acts, only 10 brands are taken from cosmetic advertisements to attract or invite products to buy. And advertising results from 10 cosmetic brands in Indonesia only got $7 \%$ speech statement, 30\% information, 9\% claim, 19\% suggestion, 9\% suggestion, $2 \%$ argument, $2 \%$ accusation, $2 \%$ referral, $16 \%$ directive, persuasion $2 \%$, promise $2 \%$. From this result that most cosmetic brands in Indonesia use information, to make it more interesting for buyers to find out more information than other advertisements.
\end{abstract}

Keywords: A speech act, Advertisement, Cosmetic

\section{INTRODUCTION}

English is a language used throughout the world. With the globalization era, English can be used to communicate with others so that it is easy to use in world education, politics, business and economics, Ashid, Nurdiansyah, Parmawati (2019). The purpose of advertising is to get the benefits of each product sold, the audience can find out the product if the product is introduced to the services offered. Strategies used to inform products to the public using marketing, marketing is an activity that is inseparable from the business activities of each product or service company, according to Rudiawati, Fitria, Syahrijal (2018), and advertising is to promote certain products. Every trading company must have a marketing strategy. According to Stanton as cited in Corredor (2019), Is a structured activity of all business activities, which intends to plan, price, promote and distribute goods or services that meet the needs of users of the products or services offered. Some components in marketing are public relations advertising, promotion and sales. To use good language and the specific purpose of communicating and speaking with needs is to use spoken language actions. According to (Levinson, 2011), as cited in Fitria (2018), pragmatic, in traditional terms consisting of studies of different "language uses", different from syntax, called "combinatorial words or parts," and semantics, "studio mean ". And also according to Mufiah and Rahman (2018), pragmatic communication is the guide of the speaker, writer, and reader.

In the use of brand advertisement, especially in cosmetics advertising usually uses several speech acts. speech act is a number of utterances with the theory of the interaction of single speech acts in written advertisements supported by the theory according to (simona andcartis, 2014), as cited in Khalis (2018), there are 16 types of speech acts, the first is Affirmation, is a statement positive claims, products, problems, recipients, addresses, usually made or used without proof. The second information refers to knowledge of the product, problem, recipient, 
service, and address. The third claim refers to a statement of truth of the product, or advertising service. The fourth suggestion refers to an indirect argument. The fifth advice refers to opinions related to the addresser. What is the attitude of the recipient? The sixth argument refers to the evidence of claims submitted. The seventh evaluation is a person's final assessment. Eight Disclaimers, referring to the previous remarks. The ninth charge refers to negative service. The tenth surprise, refers to surprises that are unexpected and usually do not occur. Eleventh, expression of thanks. The twelfth warning is an unpleasant statement. The thirteenth direction is the request for information on the fourteenth Persuasion action, referring to persuading and convincing the attractiveness of the advertised product service. Fifteenth offer, referring to the address information that has been advertised according to the product so the address must be clear and the recipient easy to check. The sixteenth promise, refers to commitments that will occur in the future. The benefits of this utterance are we can know the usefulness in which language the language is very important.

According to Mufiah, Rahman (2018), formal speech acts are committed by someone in public. From the following explanation, greeting sentences that directly contain words, suggestions, and support for specific purposes. According to (Austin, 1962; p, 108), as cited in Rakasiwi (2019), that in the pronunciation of a sentence there are three types of questions: distraction actions that use meaningful sentences (meaning study), illocutionary actions that use statements, offers, requests, appointments and questions. According to Syafitri (2018), speech acts for direct communication with command sentences will provide advice for each offer. so in each sentence, which is used with its use, it usually depends appropriate to the specific situation.

Along with the times, trends have also changed, each era has a different trend from other eras, so many products have emerged along with consumer demand, women always want to be more beautiful, demand makes the cosmetics industry survive even in crisis, cosmetics become a strong business with value increasing every year. According Li (2020), the use of cosmetic products is not only increasing for women but for men as well. Of course all types of media, advertising must have a term of seduction, which attracts the attention of customers, which means that the language of advertising has its own purpose to attract the attention of consumers which leads to actions to buy products

\section{METHOD}

This study uses a qualitative descriptive method, which analyzes speech acts from cosmetics brand advertisements in Indonesia, by analyzing sentence words from their speech acts. According to Sugiyono as cited in Cahyati, Parmawati, and Atmawidjaja (2019), Qualitative research is a method of positivism philosophy research, the use of natural objects, and as data engineering data from qualitative research result.There are 10 brands of cosmetics such as Viva cosmetics, Sari ayu, Wardah, Inez cosmetics, Make over, Emina, Mustika queen, Pixy, Garnier indonesia, Purbasari. The Data was collected and analyzed entered into the illocutionary act (Simona and Cartis, (2014) cited in Khalis (2018)).

\section{RESULTS AND DISCUSSION}

\section{Results}

The Data collection was taken from instagram posts regarding each product and selected the text would be analyzed using the theory of speech act proposed by simona andcartis (2014) 
cited in Khalis (2018). This research data is taken from 10 Indonesian Viva Cosmetics, Sari Ayu, Wardah, Inez Cosmetics, Make Over, Emina, MustikaRatu, Pixy, Garnier Indonesia, and Purbasari. Of all these products based on this research that each product contains different advertisements. Analysis of the data taken from speech acts for written advertisement can be seen below :

1. Viva cosmetic

a. Transparent gel for acne-prone skin with triple Action: sulfur, salicylic acid, and triclosan to help dry up pimples and kill the acne-causing bacteria (Claim).

b. Enriched Allantoin as Anti-Irritant and soothes the skin and pro-vitamin B5 so that the skin does not dry (Claim)

c. Easy to absorb and easy to use when doing activities without disturbing appearance (Assertion)

d. How to apply viva acne gel triple Action on acne-prone skin after the skin is clean (information)

e. Use regularly until the acne subsides (information)

f. https://www.instagram.com/p/B8q4SrKAlrD/?igshid=9w4m585n8a9h (information)

This advertisement promotes the Acne "Gel" product, the latest series released by Viva Cosmetic, enriched by Allantoin as "Anti-Irritant" which functions to promote "skin" and vitamin B5 from dryness. and free to "Activities", to better "use" routinely to invite readers and try products, procedures, using imperative verbs, which are the driving force for buying products.

\section{Sariayu}

a. Hello best friend Sariayu! You already know that Sariayu doesn't have this one product? This Foundation has 4 shades which is perfect for your dry skin you know! (information)

b. The content of sandalwood oil can make your skin moist and protected from the sun (Assertion)

c. Come on, share your experience using sari ayu foundation in the \#sariayu comment column (information)

d. https://www.instagram.com/p/B8d2XqenJXN/?igshid=1a2r9149nuwff (information)

This ad promotes foundation products from Sariayu, in the first sentence the foundation has 4 color variants for "dry" skin, and contains sandalwood oil which makes the skin "moist", and you can "share" to share experiences please write in the comments column. This ad asks the reader to buy the product, the imperative verb.

\section{Wardah}

a. Ladies express yourself with the 18 shades of wardah exclusive matte lip cream (Suggestion)

b. Every shade shows your personality (Persuasion)

c. There are shades of pink, peach, red, and also mauve nude (information)

d. VariantsExpress your mood through your lip color, cause (Argument)

e. \#oneshadeslsNeverEnough, (information)

f. Ladies! (direction)

g. https://www.instagram.com/p/B802bqHp1_n/?igshid=1juhy2dplpqbi (information) 
This advertisement promotes a lipstick color variant from Wardah Cosmetics, in the second sentence, it uses persuasion while offering "for personality use" (Imperative sentence). dikalimat next there are several color variations of this lipstick to better "invite the mood"

\section{Inez Cosmetic}

a. Beautyinez, you know the exact order of skin lightening series from Inez cosmetics? (suggestion)

b. If you are still confused (advice)

c. Let's see the exact sequence below (information)

d. Cleanser, facial foam, toner, moisturizer cream (information)

e. Don't forget to share your share in the comments column, yes (advice)

f. https://www.instagram.com/p/B7sAlGtA7Pf/?igshid=1uo7cwxaavj81 (information)

This advertisement promotes "skin lightening" product series from Inez cosmetics, in the first sentence, starting with a suggestion, the second they give advice to listen to the order of use of skin lightening. and can also "share" the results of these uses.

\section{Makeover}

a. giving y all pink with this glam romantic look using make overpower style transferproof lip cream B02 "LUCKY". (information)

b. What about you, gorgeous? (advice)

c. which pink product of use that you love the most? (suggestion)

d. drop your faves in the comment below (advice)

e. https://www.instagram.com/p/B8QOa1RHOhU/?igshid=1pm05xkrgldjy (information)

This advertisement from lipstick products from a makeover, thus making the style / appearance very "LUCKY". Find interesting to display "gorgeous", by "using" pink lipstick, and this product provides an opportunity to comment provided. by using verbs (imperatives).

\section{Emina}

a. Those who answered the previous post with bright stuff sheet mask essence for the step 2 of 11 minutes night beauty routine is right! (Accusation)

b. After washing your face, but this sheet mask on for about 15 minutes. (information)

c. You"ll get your beauty sleep and sweet dreams! (claim)

d. https://www.instagram.com/p/B8KkkkIUaa/?igshid=1afdbb1b9cggi (information)

This advertisement that masks are used routinely, there is the word "routine" that with 2 out of 11 using masks are brighter. with the word "put this" mask for 15 minutes that for information using the product, and the reader is directed with the word "get" to be more comfortable so that it will look more beautiful. 
7. MustikaRatu

a. In tropical countries and with lots of pollution, hair loss and dullness are very challenging problems to avoid (information)

b. However, there is no need to worry because the queen must provide a natural, traditional solution: (Suggestion)

c. Hair oil, friends! (direction)

d. Use 1 hour before shampooing (direction)

e. The more diligent we use the hair will be strong, not easy to fall out and beautiful shiny (information)

f. https://www.instagram.com/p/B8oDAWHJA1y/?igshid=14y5ki9y6xbt4 (information)

This advertisement says that hair loss and dullness are a challenging problem, with the word "problem", and this ad gives a suggestion with the words "No worry" so that it suggests "hair oil" and "use" 1 hour for strong hair and not fall. there is the word "hair and not fall" uses the word (imperative verb).

8. Pixy
a. NEW ARRIVAL (Direction)
b. New products from the white aqua series to clean your face quickly and easily! (Direction)
c. Can remove dirt, make-up, excess oil while making the skin smoother, moisturized and brighter (information)
d. Have you tried it? (suggestion)
e. https://www.instagram.com/p/B8Q1Kt4gukW/?igshid=1by7qdmhloqld (information).

This advertisement directs the word "New Arrival" from the latest product that is pixy white aqua also with the word "fast and easy" for more details there is the word "make skin smoother". and you can try with the word "try it".

9. Garnier Indonesia
a. There you glow! (direction)
b. Face glowing already, don't slam it (suggestion)
c. Take care of your skin every day using Garnier serum body lotus milk sakura white with extracts of sakura and UV protection that can make your skin brighter and glowing in one week (information)
d. Have you tried anything here? (suggestion)
e. Tag your friends to try, let's also \#GarnierIndonesia (direction)
f. https://www.instagram.com/p/B7u3L7_ILR-/?igshid=kqg7apui919 (information)

This advertisement directs with the word "glow", and provides information from the word "brighter" of the Garnier lotion product, this ad gives advice with the word "try". 
10. Purbasari

a. Here comes the excellent of Purbasari Pore Perfecting BB Cushion (promises)

b. Besides being able to disguise pores, it also protects facial skin from the adverse (claim)

c. Effects of sunlight with the presence of SPF 18PA. (assertion)

d. Who have you tried, Mates? (suggestion)

e. https://www.instagram.com/p/B65fVB_AO8g/?igshid=16s2n7s5stnx7 (information).

This advertisement advertises purbasari pore perfecting BB cushion with the word "excellence", protecting skin from the effects of "sunlight" with the word "disguising", and this ad suggests with the word "

Table 1. total percentage of analysis of speech act of cosmetic brand in Indonesia

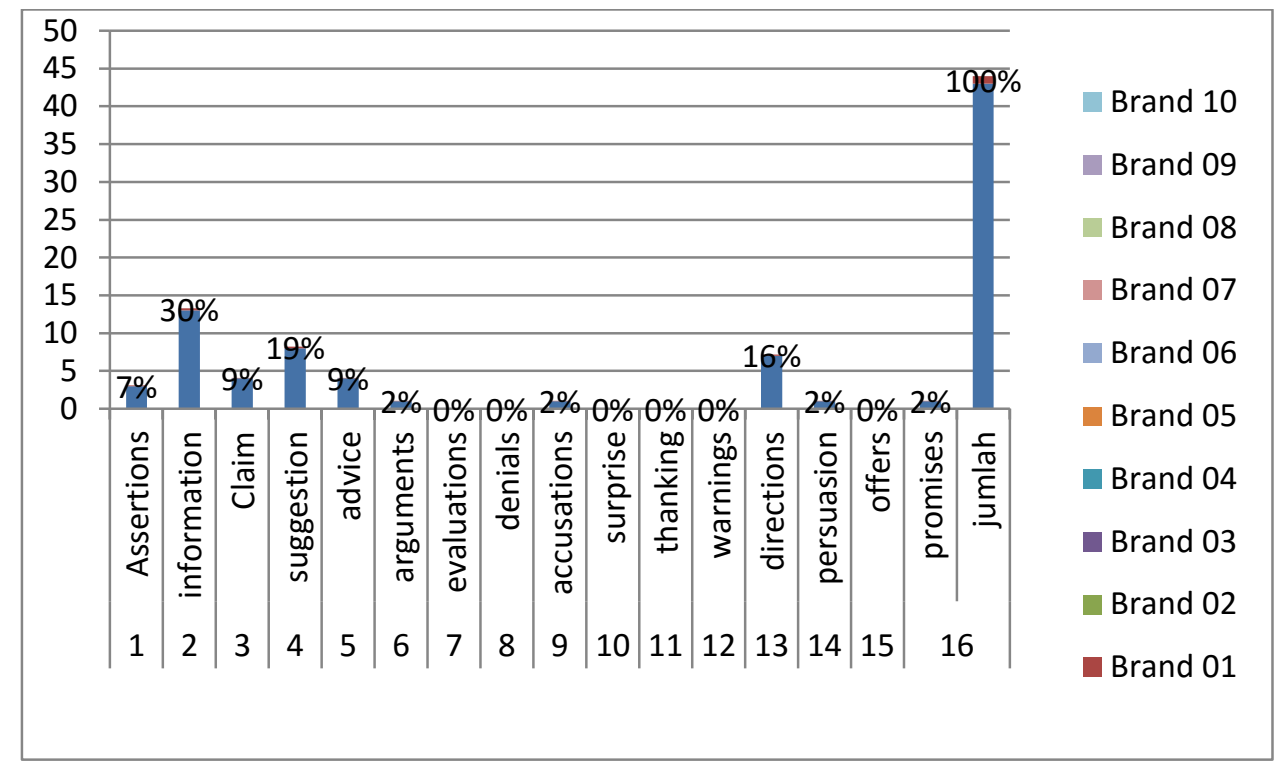

Table 1. total of analysis of speech act of cosmetic brand in Indonesia.

Based the table 1, Assertions is used speech act and have percentage 7\%, information is used speech act have percentage $30 \%$, Claim is used speech act have percentage $9 \%$, suggestion is used speech act have percentage $19 \%$, advice is used speech act have percentage $9 \%$, is used speech act have percentage $2 \%$, accusations is used speech act have percentage $2 \%$, direction is used speech act have percentage $16 \%$, persuasion is used speech act have percentage $2 \%$, promise is used speech act have percentage $2 \%$.

Based on the results of an analysis of 10 Brands of Cosmetic in Indonesia is the most used speech act information.

\section{Discussion}

Based on data that has been found from ten advertisement speech acts on Instagram, questionable speech acts of different language ad styles by (Simona and Cartis, 2014) based on the table below:

On the table analysis speech act illocutionary of cosmetic brand in Indonesia. 
Table 2.

\begin{tabular}{lllllllllllll}
\hline No & $\begin{array}{l}\text { Name Speech } \\
\text { act (indicator) }\end{array}$ & Brand 01 & $\begin{array}{l}\text { Bran } \\
\mathrm{d} \mathrm{02}\end{array}$ & $\begin{array}{l}\text { Brand } \\
03\end{array}$ & $\begin{array}{l}\text { Bran } \\
\mathrm{d} \mathrm{04}\end{array}$ & $\begin{array}{l}\text { Brand } \\
05\end{array}$ & $\begin{array}{l}\text { Bran } \\
\mathrm{d} 06\end{array}$ & $\begin{array}{l}\text { Brand } \\
07\end{array}$ & $\begin{array}{l}\text { Brand } \\
08\end{array}$ & $\begin{array}{l}\text { Brand } \\
09\end{array}$ & $\begin{array}{l}\text { Brand } \\
10\end{array}$ \\
\hline 1 & Assertions & 1 & 1 & 0 & 0 & 0 & 0 & 0 & 0 & 0 & 1 \\
\hline 2 & Information & 2 & 2 & 1 & 2 & 1 & 1 & 2 & 1 & 1 & 0 \\
\hline 3 & Claim & 2 & 0 & 0 & 0 & 0 & 1 & 0 & 0 & 0 & 1 \\
\hline 4 & Suggestion & 0 & 0 & 1 & 1 & 1 & 0 & 1 & 1 & 2 & 1 \\
\hline 5 & Advice & 0 & 0 & 0 & 2 & 2 & 0 & 0 & 0 & 0 & 0 \\
\hline 6 & Arguments & 0 & 0 & 1 & 0 & 0 & 0 & 0 & 0 & 0 & 0 \\
\hline 7 & Evaluations & 0 & 0 & 0 & 0 & 0 & 0 & 0 & 0 & 0 & 0 \\
\hline 8 & Denials & 0 & 0 & 0 & 0 & 0 & 0 & 0 & 0 & 0 & 0 \\
\hline 9 & Accusations & 0 & 0 & 0 & 0 & 0 & 1 & 0 & 0 & 0 & 0 \\
\hline 10 & Surprise & 0 & 0 & 0 & 0 & 0 & 0 & 0 & 0 & 0 & 0 \\
\hline 11 & Thanking & 0 & 0 & 0 & 0 & 0 & 0 & 0 & 0 & 0 & 0 \\
\hline 12 & Warnings & 0 & 0 & 0 & 0 & 0 & 0 & 0 & 0 & 0 & 0 \\
\hline 13 & Directions & 0 & 0 & 1 & 0 & 0 & 0 & 2 & 2 & 2 & 0 \\
\hline 14 & Persuasion & 0 & 0 & 1 & 0 & 0 & 0 & 0 & 0 & 0 & 0 \\
\hline 15 & Offers & 0 & 0 & 0 & 0 & 0 & 0 & 0 & 0 & 0 & 0 \\
\hline 16 & Promises & 0 & 0 & 0 & 0 & 0 & 0 & 0 & 0 & 0 & 1 \\
\hline
\end{tabular}

Total

43

keseluruhan

Based on the analysis in table 1, that the results found from 16 speech acts according to the theory of from (Simona and cartis, 2014) cited in Khalis (2018), from the research results of the writers of the written only 10 speech act, namely: Assertions, information, claim, suggestions, advice, arguments, accusations, directions, persuasion, and promise. total of analysis of speech act use illocutionary of cosmetic brand in Indonesia. Based the table 1, Brand 1, 2, 3, Assertions is used (3) speech act and have percentage 7\%, Brand 1, 2, 3, 4, 5, 6, 7, 8, 9 information is used (13) speech act have percentage 30\%, Brand 1, 6, 10 Claim is used (4) speech act have percentage 9\%, Brand 3, 4, 5, 7, 8, 9, 10 suggestion is used (8) speech act have percentage 19\%, Brand 4, 5 advice is used (4) speech act have percentage 9\%, Brand 3 arguments is used (1) speech act have percentage 2\%, Brand 6 accusations is used (1) speech act have percentage $2 \%$, Brand 3, 7, 8, 9 direction is used (7) speech act have percentage $16 \%$, Brand 3 persuasion is used (1) speech act have percentage 2\%, Brand 10 promise is used (1) speech act have percentage $2 \%$.

Based on the results of an analysis of 10 Brands of Cosmetic in Indonesia is the most used speech act information.

\section{CONCLUSION}

Based on data that has been analyzed from 10 advertisements from Instagram, it turns out that opinions differ from the speech acts of the theories offrom(simona and dejica cartis, 2014), as cited in khalis (2018). Cosmetic brands in Indonesia, use Assertions 7\% speech act of 3, information $30 \%$ of 13 , claim $9 \%$ of 4 , suggestion $19 \%$ of 8 , advice $9 \%$ of 4 , arguments $2 \%$ of 1 , accusations $2 \%$ of 1 , directions $16 \%$ of 7 , persuasion $2 \%$ of 1 , promises $2 \%$ of 1 . speech acts 
that are widely used to attract buyers are using information. because cosmetic brands in Indonesia prefer to use the information advertised.

\section{ACKNOWLEDGMENTS}

Alhamdulillahirabbil'alamin. All praises be to Allah SWT who allowed the researcher to finish this article. It is completed on the result of hard work, support, and guidance of several people the researcher would like to express special thanks to my parents, my friends and all participants who have been willing to participate in the settlement of this article.

\section{REFERENCES}

Cahyati, S. S., Parmawati, A., \& Atmawidjaja, N. S. (2019). Optimizing English teaching and learning process to young learners (a Case Study in Cimahi). Journal Of Educational Experts (JEE), 2(2), 107-114.

Corredor, C. (2019). Advocacy and enactment: Exercitives and acts of arguing. Research in Language, 17(1), 21-37. https://doi.org/10.2478/rela-2019-0003.

Khalis, H. (2018). Speech Acts of Written Texts in Fast Food Online Advertisement, (November).

$\mathrm{Li}, \mathrm{X}$. (2020). How powerful is the female gaze? The implication of using male celebrities for promoting female cosmetics in China. Global Media and China, 205943641989916. https://doi.org/10.1177/2059436419899166.

Mufiah, N. S., \& Nur Rahman, M. Y. (2019). Speech Acts Analysis of Donald Trump'S Speech. PROJECT (Professional Journal of English Education), 1(2), 125. https://doi.org/10.22460/project.v1i2.p125-132.

Nurdiansyah, D. M. R., Asyid, S. A., \& Parmawati, A. (2019). Using Color Coding to Improve Students'english Vocabulary Ability. Project (Professional Journal Of English Education), 2(3), 358-363. https://doi.org/10.22460/project.v2i3.p358-363.

Rakasiwi, R. (2019). JURNAL ILMIAH KOHESI Vol. 3 No.2 April 2019, 3(2), 93-95.

Rudiawati, R., Fitria, V., \& Syahrizal, T. (2018). Speech Act in Indonesias' Shampoo Advertisment. PROJECT (Professional Journal of English Education), 1(4), 427. https://doi.org/10.22460/project.v1i4.p427-435.

Simon, S., \& Dejica-Cartis, D. (2015). Speech Acts in Written Advertisements: Identification, Classification and Analysis. Procedia - Social and Behavioral Sciences, 192, 234-239. https://doi.org/10.1016/j.sbspro.2015.06.033.

Syafitri, W. (2019). An Analysis of Commissive Speech Act Used by The Shopping Hosts of MNC Shop. Jurnal Arbitrer, 6(1), 28. https://doi.org/10.25077/ar.6.1.28-34.2019. 
